\title{
Growth hormone gene polymorphism in chicken divergently selected for axial skeleton malformation
}

\author{
B. Wardęcka ${ }^{1}$, K. Jaszczak, R. Parada, M. Korczak and G. Zięba \\ Department of Molecular Cytogenetics, \\ Institute of Genetics and Animal Breeding, \\ Polish Academy of Sciences \\ Jastrzębiec, 05-552 Wólka Kosowska, Poland
}

(Received 7 June 2004; revised version 25 July 2005; accepted 4 August 2005)

\begin{abstract}
Chicken growth hormone (cGH), a polypeptyde hormone synthesized in and secreted by pituitary gland, is involved in a variety of physiological functions such as growth, body composition, egg production, aging and reproduction. Two breeds of chickens selected for high and low incidence of scoliosis, were analysed for polymorphisms in the growth hormone gene $(\mathrm{GH})$. The polymorphism of GH gene (PCR-RFLP) was analysed in 30 chickens each breed, Rhode Island Red and Sussex. It was observed five RFLPs in GH gene, three at MspI sites in the intron 1 of cGH gene and two MspI sites in the intron 4 of cGH gene. The selection for axial skeleton malformation appears to have affected the frequency of GH alleles. It was found differences in allelic distribution between the affected $(\mathrm{H})$ and unaffected $(\mathrm{L})$ lines. Whereas none of the alleles was observed as specific to $\mathrm{H}$ or $\mathrm{L}$ lines for both breeds. The experimental material examined constitutes a valuable source for identification of real genes causing skeletal defects.
\end{abstract}

KEY WORDS: divergent selection, chicken, axial skeleton defects, GH polymorphisms

\section{INTRODUCTION}

Skeleton defects are an important problem in poultry flocks, particularly in meat type birds. Reasons of the disorders are multiple and the etiology as well as the pathogenesis is till now poor defined, but the pathological changes of skeleton are hereditary (Mercer and Hill, 1984).

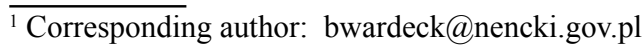


In the United States the estimated annual losses caused by skeletal problems amount to 80-120 million dollars in broiler chickens and 40 million dollars in turkeys (Morris, 1993). Poultry losses caused by skeletal problems are the result of an increased mortality and number of birds culled (caused also by septicaemiatoxaemia) and by the downgrading of breasts and legs (Sullivan, 1994). Skeletal problems are recognised as one of the four major factors limiting the performance of meat-type birds, because fast-growing broilers, reaching market weights at earlier ages, are considered to have more leg problems and suffer from greater losses than slower-growing birds (Day, 1990; Julian, 1998).

The most important inherited skeletal defects of the axial skeleton are mutations affecting the beak, head, neck and body: cerebral hernia, hereditary exencephaly, crossed beak, short mandible, short upper beak, supernumerary ribs, kyphoscoliosis, spondylolisthesis. The genetic basis of most of these skeletal disorders is still not fully understood (Somes, 1990).

The genetic of an inherited form of scoliosis in chicken was studied by Riggins et al. (1977) and McCarrey et al. (1981). Variation of expression scoliosis is attributed to incomplete penetrance of the major genes, additive effects of minor modifying genes, and primarily to environmental effects and seems to be correlated with the onset of sexual maturity (McCarrey et al., 1981). It was shown that the plasma-free hydroxyproline concentration in scoliotic birds is about twice that of normal chickens, which may reflect an abnormality in collagen metabolism (Lin et al., 1980).

Growth hormone $(\mathrm{GH})$, a polypeptide hormone synthesized in and secreted by the pituitary gland, affects a wide variety of physiological parameters such as growth, egg production, body composition, appetite control, aging and reproduction (Vasilatos-Younken et al., 1999; Putnova et al., 2001). Growth hormone gene polymorphisms have also been observed in other animals. For example, a polymorphism observed in intron 3 of bovine growth hormone (bGH) gene was found to be linked to milk protein content (Lagziel et al., 1999). In fact, regulatory elements have been identified in the intron region of the $\mathrm{GH}$ gene in various animals. A glucocorticoid regulatory element (GRE), which may be responsible for the transcriptional control of the human $\mathrm{GH}(\mathrm{hGH})$ gene, has been located in the first intron of the hGH gene (Moore et al., 1985; Slater et al., 1985). A pituitary-specific transcription factor, GHF1, which was suggested to be involved in the tissue-specific expression of the $\mathrm{GH}$ gene has also been identified in intron 3 of the rainbow trout GH gene (Bernardini et al., 1999). These investigations suggest that introns in the $\mathrm{GH}$ gene might play a crucial role in the regulation of $\mathrm{GH}$ gene expression.

Polymerase chain reaction - restriction fragment length polymorphism (PCR-RFLP) studies on artificially inseminated (AI) bulls have also revealed an association between $\mathrm{GH}$ polymorphism and AI bull reproductive performance (Lechniak et al., 1999).

The chicken $\mathrm{GH}(\mathrm{cGH})$ gene is similar to mammalian $\mathrm{GH}$ genes, containing five exons and four introns. However, the introns of cGH were significantly larger. The 
research on met type chicken using RFLP has shown that the GH gene is highly polymorphic. According to Fotouhi et al. (1993) the selection for abdominal fat appears to have affected the frequency of alleles of the growth hormone gene.

Kuhnlein et al. (1997) analysed 12 non-inbred strains of White Leghorn chicken by PCR-RFLP at three MspI sites (PM1, PM2 and PM3) and one SacI site (PS1). These sites were located at intron 1 (PM3), intron 3 (PM2), and intron 4 (PM1, PS1), respectively. The author suggested that these alleles, located within the introns, were selected either for an array of egg production traits, resistance to Marek's disease, or resistance to avian leukosis. The GH gene polymorphisms were determined by PCR-RFLP in 28 populations of native Chinese chickens by Ip et al. (2001). Yellow Wai Chow GH gene was characterized by sequencing and was found to have one silent substitution, 31 insertions, and other substitutions spread among the introns (Ip et al., 2001). Recently a novel MspI site in the 4 intron of the cGH gene was reported (Nie et al., 2002)

Our objective is to investigate the GH gene polymorphisms in divergently selected lines of chicken for skeletal defects. The allelic composition and frequencies were estimated for each chicken line. The implication of GH in a variety of physiological functions prompted us to search for DNA polymorphisms in the GH gene and test whether the incidence of such polymorphisms is affected by selection for high and low incidence of axial skeleton defects.

\section{MATERIAL AND METHODS}

\section{Experimental material}

The experimental material consisted of chickens of two breeds: Rhode Island Red (RIR) and Sussex (SX) divergently selected over six generations for high (H) or low (L) incidence of axial skeleton defects in embryos. A description of the material was previously reported by Jaszczak et al. (1999). The divergent selection was performed over six generations on the basis of the analysis frequency of axial skeleton defects (scoliosis) found in dead embryos on day 17-21 of incubation in full families of commercial RIR and SX lines. The frequency of scoliosis in dead embryos in RIR chickens was $40 \%$ in $\mathrm{H}$ lines and $4.1 \%$ in L lines, while in SX chickens, it was $19.5 \%$ in $\mathrm{H}$ lines and 3.3\% in $\mathrm{L}$ lines.

Blood samples were collected into vacuum tubes containing EDTA and stored at $-20^{\circ} \mathrm{C}$. The DNA was extracted by standard methods. DNA concentration was determined spectrophotometrically and DNA was diluted to a final concentration of $0.1 \mu \mathrm{g} / \mu \mathrm{l}$.

The analysis of polymorphism in intron 1 and 4 of the GH was performed for 60 individuals - 30 per breed ( 15 per line with high or low incidence of axial skeleton defects). 
PCR-RFLP of intron lof GH gene

Intron 1 was amplified by PCR and two primers were

5'- ATCCCCAGGCAAACATCCTC (PM3 forward) and

5'- CCTCGACATCCAGCTCACAT (PM3 reverse).

The PCR conditions used comprised an initial denaturation step of $95^{\circ} \mathrm{C}$ for $5 \mathrm{~min}, 35$ cycles of denaturation at 94 for $30 \mathrm{sec}$, annealing at $60^{\circ} \mathrm{C}$ for $2 \mathrm{~min}$, and an extension step of 72 for $90^{\circ} \mathrm{C} \mathrm{sec}$.

PCR-RFLP of intron 4 of GH gene

Intron 4 was amplified by PCR and two primers were

5'- CTAAAGGACCTGGAAGAAGGG (PM1 forward) and

5'- AACTTGTCGTAGGTGGGTCTG (PM1 reverse).

The PCR conditions used comprised an initial denaturation step of $95^{\circ} \mathrm{C}$ for $5 \mathrm{~min}, 35$ cycles of denaturation at $94^{\circ} \mathrm{C}$ for $30 \mathrm{sec}$, annealing at $62^{\circ} \mathrm{C}$ for $2 \mathrm{~min}$, and an extension step of 72 for $90^{\circ} \mathrm{C} \mathrm{sec}$.

The used primers were described previously by Kuhnlein et al. (1997) and gave a predicted product of $776 \mathrm{bp}$ for PCR-RFLP of intron 1 (Ip et al., 2001) and 1170 bp for PCR-RFLP of intron 4 (Nie et al., 2002).

The PCR was carried out in a volume of $25 \mu \mathrm{l}$ comprising $100 \mathrm{ng}$ of template DNA, 2.5 pmol of each primer, $100 \mu \mathrm{M}$ of each dNTP, 0.5 unit of DNA polymerase, $10 \mathrm{mM}$ tris- $\mathrm{HCl}(\mathrm{pH} 8.8) 1.5 \mathrm{mM} \mathrm{MgCl}, 50 \mathrm{mM} \mathrm{KCl}$ and $0.1 \%$ Triton X-100. The PCR was performed using a PTC-200 Programmable Thermal Controller (MJ-Research).

The PCR products of intron 1 and $4(8-12 \mu \mathrm{l})$ were digested overnight at $37^{\circ} \mathrm{C}$ with $M s p \mathrm{I}$ in a reaction mix that contained $1 \mu \mathrm{l}$ restriction enzyme (about $5 \mathrm{U}$ ), $1.5 \mu \mathrm{l}$ of reaction buffer and analysed by electrophoresis in a $2 \%$ agarose gel containing ethidium bromide.

The frequency of alleles and genotypes in analysed regions of gene cGH for 60 animals were than calculated.

\section{RESULTS}

PCR-RFLP of intron 1/MspI of gene cGH

A PCR product of expected size, $776 \mathrm{bp}$, was observed in intron 1 of $\mathrm{cGH}$ gene. Ten genotypes were determined by alleles 1, 2, 3, 4 and 5 were identified in intron 1, and three polymorphic $M s p I$ sites were identified.

Allele 1 had one MspI site $a$ only, producing two fragments of about 237 and $539 \mathrm{bp}$. Allele 2 had one MspI site $b$ only, producing two fragments of 362 and 
$414 \mathrm{bp}$. Allele 3 had two MspI sites $a$ and $b$, in which fragments of 237, 125 and 414, bp were generated. Allele 4 had two $M s p I$ sites $b$ and $c$, in which fragments of 362, 267 and $147 \mathrm{bp}$ were generated. Allele 5 had three $M s p I$ sites $a, b$ and $c$, in which fragments of 237, 125, 267, $147 \mathrm{bp}$ were generated (Figure 1).

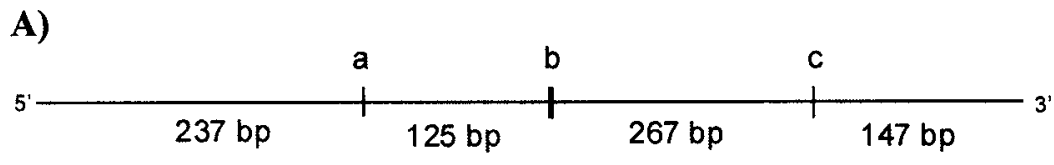

B)

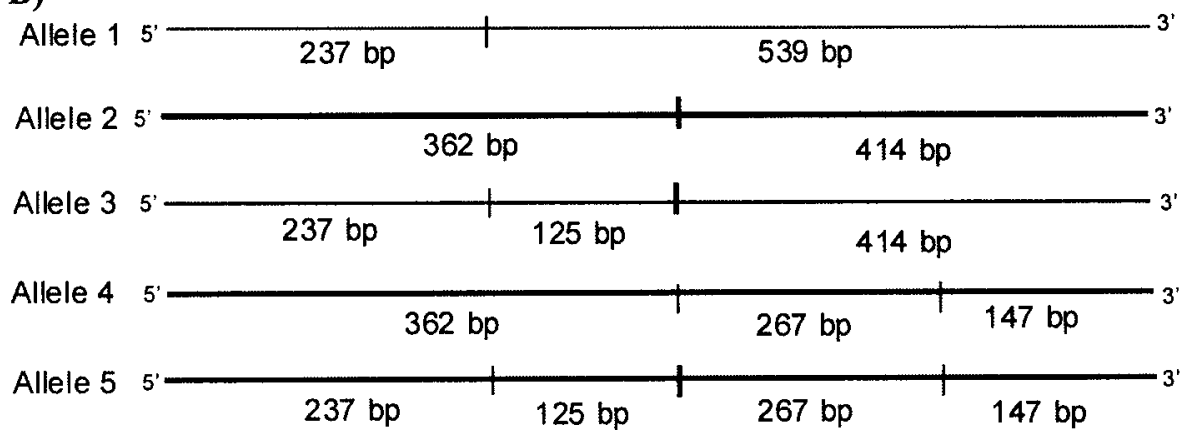

Figure 1. RFLP and mapping of the MspI polymorphism in the first intron of the GH gene. A) Restriction map of intron 1. B) Alleles of intron 1 identified in analysed animals

Genotype $1 / 1$ was a homozygote determined by allele 1 , Genotype $4 / 4$ was a homozygote determined by allele 4 , and Genotype $5 / 5$ was homozygote determined by allele 5 . Genotypes $1 / 2,1 / 3,1 / 4,1 / 5,2 / 3,2 / 4$ and $3 / 5$ were heterozygotes consisting of alleles $1,2,3,4$ and 5 (Table 1).

TABLE 1

Genotypes of RFLP polymorphism at the MspI site at intron 1 of GH gene.

\begin{tabular}{cc}
\hline Genotypes & Restriction fragments bp \\
\hline $1 / 1$ & 237,539 \\
$2 / 1$ & $237,362,414,539$ \\
$3 / 1$ & $237,125,414,539$ \\
$4 / 1$ & $147,237,267,362,539$ \\
$5 / 1$ & $125,147,237,267,539$ \\
$4 / 2$ & $147,267,362,414$ \\
$3 / 2$ & $125,237,362,414$ \\
$3 / 5$ & $125,147,237,267,414$ \\
$4 / 4$ & $147,267,362$ \\
$5 / 5$ & $125,147,237,267$ \\
\hline
\end{tabular}




\section{PCR-RFLP of intron 4/MspI of gene cGH}

Two polymorphic Msp I sites in PCR product of expected size, $1166 \mathrm{bp}$, were identified. The six genotypes were determined by alleles $\mathrm{A}, \mathrm{B}$, and $\mathrm{C}$ were identified in intron 4. Allele A had no MspI site. Allele B had one Msp I site $c$ only, producing two fragments of $588 \mathrm{bp}$ and 578, which appeared as one band. Allele C had one MspI site $d$ only, in which fragments of about 416 and 750 bp were generated.

Genotype A/A was a homozygote determined by allele $\mathrm{A}$, genotype $\mathrm{B} / \mathrm{B}$ was a homozygote determined by allele $\mathrm{B}$, and genotype $\mathrm{C} / \mathrm{C}$ was homozygote determined by allele $\mathrm{C}$. Genotypes $\mathrm{A} / \mathrm{B}, \mathrm{A} / \mathrm{C}, \mathrm{B} / \mathrm{C}$ were heterozygotes consisting of alleles $\mathrm{A}, \mathrm{B}$ and $\mathrm{C}$ (Figure 2; Table 2).

A)

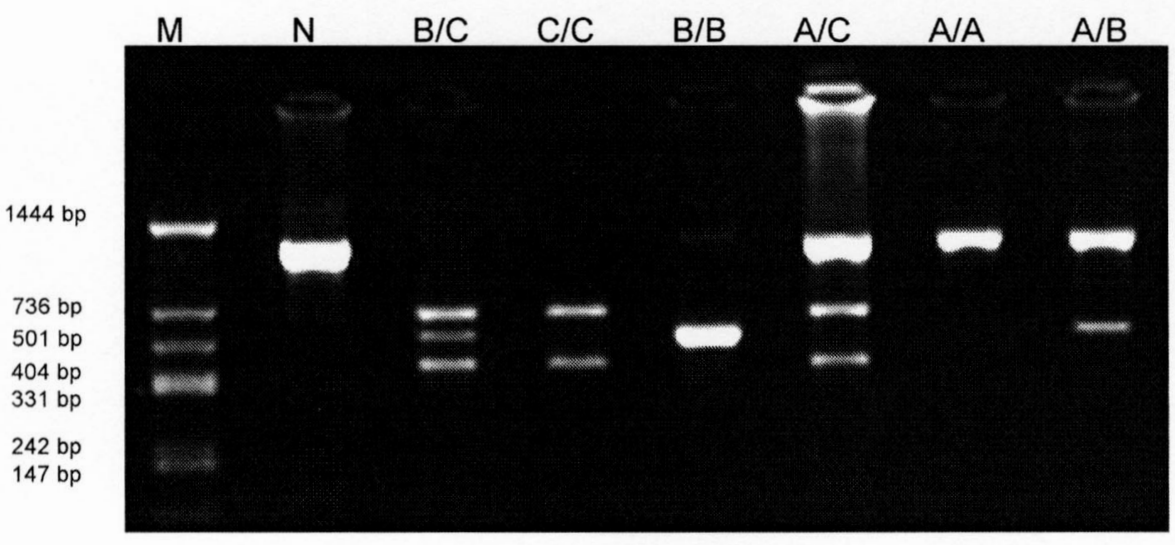

B)

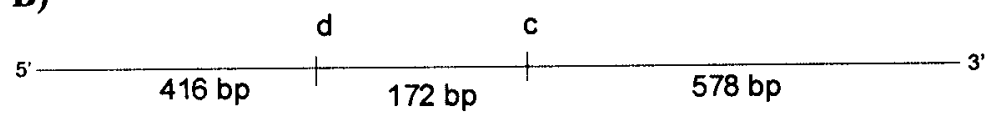

C)

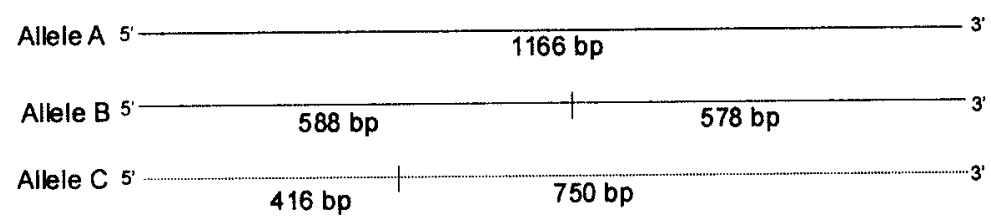

Figure 2. RFLP of the MspI polymorphism in intron 4 of the chicken growth hormone gene. A) Profiles of intron 4. M- DNA marker 80-1444 bp (Msp I digest of pUC19), N-PCR product, genotypes: B/C, C/C, B/B, A/C, A/A, A/B. B) Restriction map of intron 4. C) Alleles of intron 4 identified in analysed animals 
TABLE 2

Genotypes of RFLP polymorphism at the MspI site at intron 4 of GH gene

\begin{tabular}{cc}
\hline Genotypes & Restriction fragments, bp \\
\hline $\mathrm{A} / \mathrm{A}$ & 1166 \\
$\mathrm{~B} / \mathrm{B}$ & 578,588 \\
$\mathrm{C} / \mathrm{C}$ & 416,750 \\
$\mathrm{~A} / \mathrm{B}$ & $578,588,1166$ \\
$\mathrm{~A} / \mathrm{C}$ & $416,750,1166$ \\
$\mathrm{~B} / \mathrm{C}$ & $416,750,578,588$ \\
\hline
\end{tabular}

TABLE 3

Frequency of alleles (\%) of intron 4 and 1 of GH gene for RIR and SX chicken lines with high (H) or low (L) incidence of axial skeleton defects

\begin{tabular}{|c|c|c|c|c|c|}
\hline \multirow{3}{*}{ Alleles of intron 1} & \multicolumn{5}{|c|}{ Frequency of alleles $\%$} \\
\hline & \multicolumn{2}{|c|}{$\mathrm{H}$ lines } & \multicolumn{2}{|c|}{ L lines } & \multirow{2}{*}{ all lines } \\
\hline & $\mathrm{SX}$ & RIR & $\mathrm{SX}$ & RIR & \\
\hline 1 & 0.0 & 66.6 & 33.3 & 73.3 & 44.0 \\
\hline 2 & 35.7 & 0.0 & 20.0 & 3.3 & 14.4 \\
\hline 3 & 10.7 & 0.0 & 6.6 & 6.6 & 5.9 \\
\hline 4 & 53.5 & 6.6 & 26.6 & 3.3 & 22.0 \\
\hline \multirow[t]{2}{*}{5} & 0.0 & 26.6 & 13.3 & 13.3 & 13.5 \\
\hline & \multicolumn{5}{|c|}{ Frequency of alleles \% } \\
\hline \multirow[t]{2}{*}{ Alleles of intron 4} & \multicolumn{2}{|c|}{$\mathrm{H}$ lines } & \multicolumn{2}{|c|}{ L lines } & \\
\hline & SX & RIR & $\mathrm{SX}$ & RIR & all lines \\
\hline A & 57.1 & 13.3 & 73.3 & 6.6 & 37.2 \\
\hline B & 42.8 & 0.0 & 26.6 & 23.3 & 22.8 \\
\hline C & 0.0 & 86.6 & 0.0 & 70.0 & 39.8 \\
\hline
\end{tabular}

Allele frequencies of $\mathrm{H}$ and $\mathrm{L}$ lines of RIR and SX chickens in intron 1 and 4 are shown in Table 3. It was found differences in allelic distribution between the affected $(\mathrm{H})$ and unaffected $(\mathrm{L})$ lines. None of the alleles was observed as specific to $\mathrm{H}$ or $\mathrm{L}$ lines in both breeds simultaneously.

For the SX breed specific alleles for L lines were identified in intron $1 / M s p$ I (allele 1, allele 5). For the RIR breed specific alleles for $\mathrm{L}$ lines were identified in intron 1/MspI (allele 2, allele 3), PCR - RFLP of intron 4/ MspI (allele B).

Genotype frequencies of $\mathrm{H}$ and $\mathrm{L}$ lines of RIR and SX chickens in intron 1 and 4 are shown in Table 4 . Specific genotypes for $\mathrm{H}$ lines were identified only in intron 1/MspI: $1 / 5$ - for the RIR breed, 2/3 - for the SX breed. Specific genotypes for L lines were identified in intron 1/MspI:1/2,3/5- for the SX breed $1 / 3$ - for the RIR breed, and PCR-RFLP of intron 4/MspI: B/C - for the RIR breed. 


\section{DISCUSSION}

Similar to GH genes identified in other mammals, the cGH gene consists of five exons and four introns. It has been reported that the size of the cGH gene is about 3.5 kb (Tanaka et al., 1992; Mou et al., 1995; Ip et al., 2001). RFLPs have been characterized in the introns of cGH gene of White Leghorn and it has been suggested that the alleles identified were linked to egg production traits, resistance to Marek's disease, and avian leukosis (ALV) (Kuhnlein et al., 1997). PCR-RFLPs of the cGH gene were also studied in various populations of Chinese native chickens and it was suggested that an allele present in intron 1 might be linked to laying performance (Ip et al., 2001).

We assumed that our experimental material became fixed as regards scoliosis alleles at all major loci because of inbreeding and selection. It was created from closely related lines (after 5 generations the coefficient of inbreeding amounted to 20.9 and $14.2 \%$ in RIR chickens and 14.4 and $11.0 \%$ in SX chickens for lines $\mathrm{H}$ and $\mathrm{L}$, respectively).

In lines selected for high axial skeletal deformations, a higher mortality of embryos was observed - total losses during the hatching period in $\mathrm{H}$ and $\mathrm{L}$ lines were 42.5 and $33.0 \%$ in the RIR breed and 30.6 and $24.4 \%$ in the SX breed, respectively (Jaszczak et al., 1999). The frequency of chromosome abnormalities occurring at the early embryo stages, was significantly lower in the unaffected lines (2.4\%) than in lines with developmental spine disturbances (5.7\%) (Pryszcz et al., 1999).

The material described was screened for genomic variation on the basis of DNA fingerprinting. An analysis of the representative DNA fingerprinting band patterns led to the identification of specific bands for chicken families with a high or low incidence of axial skeleton defects. The Hinfl enzyme/33.6 probe combination produced 30 bands with different frequencies in each family. The average band sharing between lines with a high or low incidence of axial skeleton defects was 0.79 , while between families within lines selected for high or low incidence of axial skeleton defects, it was 0.97 and 0.98, respectively (Jaszczak et al., 2001).

As a result of the analysis polymorphism of 15 microsatellite loci in Rhode Island Red (RIR) and Sussex (SX) chickens, divergently selected over six generations for high $(\mathrm{H})$ or low $(\mathrm{L})$ incidence of axial skeleton defects in embryos, 8 specific alleles were identified for $\mathrm{H}$ lines and 6 specific alleles for $\mathrm{L}$ lines. None of the alleles observed was specific to $\mathrm{H}$ or L lines in both breeds simultaneously (Wardęcka et al., 2004).

The results of our study confirm that analysed region of cGH are highly polymorphic. The selection for a high or low level of axial skeleton defects 
in embryos, respectively, had different effects on the frequencies of alleles of the analysed loci. A further analysis is needed to check new polymorphisms in chicken growth hormone gene and associations with axial skeleton defects.

Because of similarities in the expression of this disease in chickens and humans, an investigation of the disease loci in chickens may provide useful insights into locating genes affecting adolescent idiopathic scoliosis in humans (McCarrey et al., 1981). Chicken lines selected for high or low skeletal defects constitute a valuable source enabling the identification of real genes causing the effect of interest.

\section{REFERENCES}

Bernardini S., Argenton F., Vianello S., Colombo L., Bortolussi M., 1999. Regulatory regions in the promoter and third intron of the growth hormone gene in rainbow trout, Oncorhynchus mykiss Walbaum. Gen. Comp. Endocrinol. 116, 261-271

Day E.J., 1990. Future research needs focus on new, old problems. Feedstuffs 62 (32), 12-15

Fotouhi N., Karatzas C.N., Kuhnlein U., Zadworny D., 1993. Identification of growth hormone DNA polymorphisms which respond to divergent selection for abdominal fat content in chickens. Theor. Appl. Genet. 85, 931-936

Ip S.C., Zhang X., Leung F.C., 2001. Genomic growth hormone gene polymorphism in native Chinese chicken. Exp. Biol. Med. 226, 458-462

Jaszczak K., Pryszcz W., Jaszczak J., Zięba G., 1999. Chromosome abnormalities in early embryos from chicken divergently selected for embryo skeletal deformations. In: Proceedings of Poultry Genetics Symposium, Mariensee (Germany), p. 122

Jaszczak K., Sacharczuk M., Parada R., 2001. Evaluation by DNA fingerprinting of the genomic variation between chicken lines divergently selected for skeletal defects. In: Proceedings of Poultry Poultry Genetics Symposium, Godölö (Hungary), p.121

Julian R.J., 1998. Rapid growth problems: ascites and skeletal deformities in broilers. Poultry Sci. $77,1773-80$

Kuhnlein U., Liu N., Weigend S., Gavora J.S., Fairfull W., Zadworny D., 1997. DNA polymorphisms in the chicken growth hormone gene: response to selection for disease resistance and association with egg production. Anim. Genet. 28, 116-123

Lagziel A., Lipkin E., Ezra E., Soller M., Weller J.I., 1999. An MspI polymorphism at the bovine growth hormone $(\mathrm{bGH})$ gene is linked to a locus affecting milk protein percentage. Anim. Genet. 30, 296-299

Lechniak D., Machnik G., Szydlowski M., Świtonski M., 1999. Growth hormone gene polymorphism and reproductive performance in AI bulls. Theriogenology 52, 1145-1152

Lin H.J., Benson R.S., Riggins R.S., Rucker R.B., Abbott U.K., 1980. Plasma free hydroxyproline, growth, and sexual maturity in the scoliotic chicken. Proc. Soc. Exp. Biol. Med. 165, 345-348

MacCarrey J.R., Abbot U.K., Benson D.R., Riggins R.S., 1981. Genetics of scoliosis in chickens. J. Hered. 72, 6-10

Mercer J.T., Hill W.G., 1984. Estimation of genetic parameters for skeletal defects in broiler chickens. Heredity 53, 193-203

Moore D.D., Marks A.R., Buckley D.I., Kapler G., Payvar F., Goodman H.M., 1985. The first intron of the human growth hormone gene contains a binding site for glucocorticoid receptor. Proc. Nat. Acad. Sci. USA 82, 699-702 
Morris M.P., 1993. National survey of leg problems. Broiler Ind., May, 20-24

Mou L., Liu N., Zadworny D., Chalifour L., Kuhnlein U., 1995. Presence of an additional PstI fragment in intron 1 of the intron 1 of the chicken growth hormone-encoding gene. Gene 160, 313-314

Nie Q., Ip S.C., Zhang X., Leung F.C., Yang G., 2002. New variations in intron 4 of growth hormone gene in Chinese native chickens. J. Hered. 93, 277-279

Pryszcz W., Jaszczak K., Jaszczak J., Brzęk A., 1999. Chromosome aberrations in chicken embryos from families with developmental abnormalities of spine. Ann. UMCS 27, 33 Sect. EE, 259-263

Putnova L., Krenkova L., Vrtkova I., Dvorak J., Pietruszka A., Czarnecki R., 2001 Association od the DdeI growth hormone gene polymorphism with some performance traits in Polish Large White and Czech Large White x Polish Large White pig. J. Appl. Genet. 42, 317-24

Riggins R., Abbott U., Ashmore C., Rucker R., Mccarrey J.R., 1977. Scoliosis in chicken. J. Bone Joint Surg. Amer. Vol. 59, 1020-1026

Slater E.P., Rabenau O., Karin M., Baxter J.D., Beato M., 1985. Glucocorticoid receptor binding and activation of a heterologous promoter by dexamethasone by the first intron of the human growth hormone gene. Mol. Cell Biol. 5, 2984-2992

Somes R.G., 1990. Mutations and major variants of muscles and skeleton in chickens. R.D. Crawford (Editor). In: Poultry Breeding and Genetics. Elsevier, pp. 209-237

Sullivan T. W., 1994. Skeletal problems in poultry: estimated annual cost and descriptions. Poultry Sci. $73,869-882$

Tanaka M., Hosokawa Y., Watahiki M., Nakashima K., 1992. Structure of the chicken growth hormone-encoding gene and its promoter region. Gene 112, 235-239

Vasilatos-Younken R., Wang X.H., Zhou Y., Day J.R., McMurtry J.P., Rosebrough R.W., Decuypere E., Buys N., Darras V., Beard J.L., Tomas F., 1999. New insights into the mechanism and actions of growth hormone (GH) in poultry. Domest. Anim. Endocrinol. 17, 181-90.

Wardęcka B., Jaszczak K., Pierzchała M., Parada R., Korczak M., 2004. Divergent selection for skeletal malformations in chickens alters polymorphism at microsatellite loci. J. Appl. Genet. $45,61-71$

\section{STRESZCZENIE}

\section{Polimorfizm genu hormonu wzrostu u kur selekcjonowanych rozbieżnie na wady embrionalne szkieletu osiowego}

Hormon wzrostu kury (cGH) wpływa na wiele cech ekonomicznie ważnych u tych ptaków, tj. wzrost, masę ciała, reprodukcję i nieśność. Dwie rasy Rhode Island Red i Sussex selekcjonowano rozbieżnie przez sześć pokoleń na wady embrionalne szkieletu osiowego. Przeanalizowano polimorfizm genu hormonu wzrostu u 30 ptaków każdej rasy, stosując metodę RFLP-PCR. Zidentyfikowano 3 mutacje w intronie 1/MspI i 2 mutacje w intronie 4/MspI genu hormonu wzrostu. Selekcja na embrionalne wady szkieletu osiowego wpłynęła na różnice w rozkładzie i frekwencji alleli pomiędzy liniami L i H. Wynik ten może być spowodowany bezpośrednim wpływem allelu GH na cechę, bądź odzwierciedla sprzężenie allelu GH z genem determinującym skoliozę. Nie znaleziono alleli specyficznych dla lini H lub L dla obydwóch ras. Materiał doświadczalny jest wartościowym źródłem dla poszukiwania genów warunkujących wady szkieletu osiowego u kur. 